The final, definitive version of this paper has been published in The Journal of Men's Studies, Vol. 27(2), 2019, pp. 169-182. Copyright (C) 2018 SAGE Publications

DOI: https://doi.org/10.1177/1060826518801531

To cite this article: Pérez-Gil, María del Mar. "Representations of Nation and Spanish Masculinity in Popular Romance Novels: The Alpha Male as 'Other'”. The Journal of Men's Studies 27.2 (2019): 169-182 https://doi.org/10.1177/1060826518801531

\title{
Representations of Nation and Spanish Masculinity in Popular Romance Novels: The Alpha Male as "Other"
}

\section{María del Mar Pérez-Gil}

\begin{abstract}
The alpha hero embodies the hegemonic masculinity that has long dominated romance fiction. The portrayal of this male type is, however, problematized when he is an exotic foreigner, as his hyper-heterosexualized masculinity is often associated with the gender backwardness of his country. This article is concerned with popular romance novels set in Spain in the 1970s. It explores how British authors rely on gender and national clichés that construct an essentialized image of Spanish men. The primitive and instinctual masculinity attributed to them reveals these novels' complicity with the ideology of Britain's superiority.
\end{abstract}

\section{Keywords}

popular romance novels, hegemonic masculinity, Spain, stereotypes, colonial discourse

Although many barriers must still be overcome, the growing number of scholarly studies that focus on popular romance novels suggests that the academic reservations about this genre seem more and more to be a thing of the past. Beneath a simple love plot lie questions of 
gender, class, race, and ethnicity that merit deeper analysis. Romance novels are a measure of the changes taking place in society, including those affecting men. It is interesting, then, to look at these texts for the insights they can provide into dominant and marginalized constructions of masculinity.

The period between the 1960s and the 1980s was the heyday of the alpha-male hero in romance fiction. At a time when second-wave feminism was forcing British men to rethink their masculinity and adjust to women's demands for equality and liberation, romance novels went against the tide by idealizing and eroticizing the phallic power of the alpha man. Even so, the Women's Liberation Movement influenced authors to create independent heroines who criticize male oppression. In the novels featuring exotic alpha heroes, this criticism is more intense. The reason, however, is not to be found only in the authors' new feminist consciousness.

Many British romance novels from the 1960s and 1970s are set in southern Europe. In these decades, countries like Spain, Portugal, Italy, and Greece appeared to the British as less developed. Narrative depictions of the hero are culturally determined and present a typically stereotyped image of exotically dark, virile masculinity. References to the status of women abound in the novels, which convey the patriarchal stasis of southern Europe. For example, in The Tower of the Captive (1966), Violet Winspear writes that "at heart the Spaniard is a primitive, and his wife his possession” (p. 123). In Kathryn Blair's A Nurse at Barbazon (1964), readers learn that freedom is "denied to the majority of Portuguese women" (p. 142) and that "acquiescence to the masculine will ... is an essential part" of their character (p. 78). In The Child of Judas (1976), Winspear states that, in Greece, a married woman “doesn't look at other men unless she wants a beating” (p. 65). The formulaic repetition of gender clichéseven by authors who never visited these countries nor set foot out of Britain, as is the case of 
Winspear (McAleer, 1999, pp. 124-125)—serves the purpose of extoling the superior British values and strategically placing this nation at the top of the hierarchy.

This article analyzes the figure of the alpha-male hero in British romance novels set in Spain in the 1970s. I will explore the conflict between the new masculinity of Englishmen and the primitive, instinctual masculinity of the Spanish alpha hero. Even though the novels privilege the exotic hero, his othering and stereotypification in terms of gender reveals a colonial discourse rooted in the entrenched belief in Britain's national superiority. In these narratives, eroticization and abjection work together to produce the alpha hero, whose masculinity is exotically idealized ${ }^{1}$ and ethnically othered.

Studies on the representation of Spanish masculinities have grown in number over the last decade, with a focus on literature and cinema (see, for instance, Fouz-Hernández \& MartínezExpósito, 2007; Cartagena Calderón, 2008; Armengol-Carrera, 2012; Hartson, 2017; Ryan \& Corbalán, 2017); historical and sociological issues (Aresti, 2012; Borràs Català, Moreno Colom, Castelló Santamaría \& Grau Casajust, 2012; Nash, 2014; Aresti \& Martykánová, 2017), and questions of homosexuality (Guasch, 1995, 2011; Aliaga \& Cortés, 2000). ${ }^{2}$ However, no attention has been paid to the representation of Spanish masculinity in romance fiction. This is the more surprising when we consider that these novels enjoy a wide international readership, and that they reproduce some of the most popular and essentialist stereotypes concerning Spain and Spanish men.

The first section of this article examines the figure of the exotic alpha hero in the context of the 1970s debate on masculinity. My discussion not only takes into account questions of gender but considers the alpha male within the discourse of colonialism and ethnicity. The remaining sections will focus on the stereotypical construction of Spanish men in British romance novels. 


\section{The gendered and colonial discourse of exotic masculinity}

Romance heroes can be regarded as "fantasy figures" (Connell, 1987, p. 184) and "Platonic Forms" existing "in some ahistorical, idealized realm" (Brod, 2011, p. 26). The kind of masculinity they represent is, as Jonathan A. Allan says, "inaccessible to almost all men" (2016b, p. 37). The long-standing hegemony of the alpha male has been unrivalled by any other romance hero so far. Wild, passionate, and autocratic, the alpha hero "embodies patriarchal power in all its glory" (Frantz, 2009, n. p.). He is "powerful, domineering, arrogant, immensely wealthy and endowed with rugged good looks" (Bach, 1997, p. 28). The alpha hero must exude virility and be the biologically and aesthetically fittest man in the novel. His splendidly masculine body is an emblem of his power.

That this hero type should rise to ascendancy in the novels from the 1960s and 1970s is paradoxical at the least. This period was one of profound changes, particularly in terms of gender. In the 1970s, the Women's Liberation Movement fought steadfastly against patriarchal thought and institutions. The gay movement gained increasing public notoriety and alternative aesthetics such as those of glam rock stars came on the scene. Jay Dixon and Jayashree Kamblé trace the emergence of the alpha hero to the 1960s and relate his rise to social factors. For Dixon, the alpha hero represents the stability and authority needed at a time of conflict marked by "student riots, the civil rights movement and demands for both sexual liberation and women's liberation" (1999, p. 63). The Latin and Arab hero typified, for the writers at Mills \& Boon, the hypermasculinity they felt lacking in British men.

Unlike Dixon, Kamblé contends that Mills \& Boon's choice of the alpha hero was a reaction against the growing social visibility of gay men. In a conservative manner supportive of established gender roles and family values, British romance novels favor the heterosexualized masculinity of the alpha hero, which reaches its apex with Arab and Latin 
men. Their "potentially reactionary beliefs about women" (2014, p. 100) were a way to reaffirm heterosexuality and counteract the homosexual threat.

Romance novels published between the late 1960s and the early 1980s are, at any rate, ambivalent texts where dominant alpha heroes exist side by side self-assertive heroines who defend their own independence, albeit temporarily, since the feminist discourse gradually wanes as the story moves to the end. Some of these novels also expose the conflict between the alpha hero and the so-called new man. The latter appeared at the end of the 1960s and in the 1970s (Beynon, 2002, p. 119) and was a by-product of second-wave feminism. ${ }^{3} \mathrm{He}$ did not identify with the concept of patriarchal masculinity and tried to liberate himself from it. The new man “willingly supported the women's movement and taking a full role in the domestic arena (particularly in respect of child-rearing)" (Beynon, 2002, p. 100). Some of the traits associated with him were typically feminine, such as "emotionality, intimacy, nurturing and caring" (Gill, 2003, p. 42). This man entered into more egalitarian relationships with his love partners and female coworkers.

Scholars have explored the crisis of the patriarchal model in the 1970s and how it is reflected in the society, economy, literature, and cinema of this period. Popular romance fiction also provides solid ground for approaching this debate. For example, in Olive Island (1972), a novel set in Greece, Kay Thorpe has the characters discuss on several occasions the changes brought about by the Women's Liberation Movement. The exotic hero asserts that, in England, "the men have forgotten how to be men," since they "allow their womenfolk to rule them" (p. 20), to which protagonist Nicky replies that what women actually demand is the right to be treated as equals, something that a few men in England are "beginning" (p. 20) to acknowledge. For Lee Merril, Nicky's friend, the Englishwomen's desire to reform the "purely masculine male," "soften him up," and "bring him to heel," will cause that in twenty years' time women will complain that “men aren't men any more” (p. 70), without accepting 
responsibility in bringing them down. In Winspear's The Child of Judas (1976), the Greek hero observes that "there would be less discontent in the hearts" of Englishwomen "if the men would remember their true role in life and cease to be so soft and easy-going” (p. 87). In another of her novels, The Kisses and the Wine (1973), she writes that the "air of good companionship so prevalent in England [is] absent from the man-woman relationship in Spain," where there is a "deeper awareness of men as men, and women as women" (p. 61). This attempt to delimit gender roles extends to the concept of masculinity. In Olive Island, Thorpe distinguishes between the "masculine" (p. 71) and the "purely masculine male" (p. 70). The "man-as-nurturer" type (Beynon, 2002, p. 100) represented by Lee Merril falls into the former category; in contrast, the alpha male exudes sexual attraction and his pure masculinity is given a privileged position in the narrative.

The two-suitor convention dramatizes the conflict between the new and traditional masculinity embodied in the kind and supportive English suitor and the manly alpha hero, respectively. The English suitor is caring and open-minded. He treats the heroine as an equal and takes for granted her right to freedom and a career. He is "kind, dependable, honest, and trustworthy" (p. 133), as Kay Thorpe describes him in An Apple in Eden (1973). He would make an ideal husband for any woman: dedicated, "ebullient, very British," and "uncomplicated" (p. 45), as we read in Pippa Lane's Nurse in Tenerife (1978). However, he is colorless, when compared to the Latin hero, and lacks the fire of passion. He "would never make the blood thunder" through a woman's body, writes Katrina Britt in The Villa Faustino (1977, p. 166). Even if the English suitor represents a non-patriarchal model of masculinity, life with him, though "pleasant and bearable" (Britt, 1977, p. 166), would ultimately be ordinary and dull. The heroine prefers the "purely masculine male" epitomized by the exotic hero. The "ideal" of maleness he symbolizes, after the process of taming is narratively completed, combines "masculine power and prestige" with the more feminine qualities of 
tenderness, caring, nurturing, and affection (Radway, 1991, pp. 127, 128). This tenderness, however, is always positional, never political (as would be that of the new man), since it is focused on one woman. At heart, the exotic hero remains a truly masculine man.

His alpha masculinity generally stands as a metonymic representation of his nation's backwardness. The taming of the exotic hero into a tender, sensitive man is a white woman's fantasy in which she reforms the dark, ethnic Other without having him renounce to his masterful virility. The novels exalt the moral and national superiority of Britain through the heroine, whose advanced views conflict with the hero's patriarchalism. One way in which national superiority is asserted is through the strategic use of the discourse of gender. In Britain, the relationship between the sexes is more civilized and evolved, in contrast to the “feudal” way (Blair, 1980, p. 117; Thorpe, 1973, p. 20; Winspear, 1979, p. 86) in which women are treated in southern Europe.

The exoticization and eroticization of the hero's darkness brings some of these novels close to the ideology of colonialism. The white gaze constructs the hero's darkness as intensely erotic. He is the "racially other" eroticized by white (northern) Europeans (Godsland, 2006, p. 234). As happens with the sheikh in desert romances (Taylor, 2007; Jarmakani, 2015; Burge, 2016), darkness marks the Latin hero out as different through an iterative rhetoric that exoticizes, eroticizes, and others him. While frequent references to his dark hair, black eyes, and olive skin are intended to heighten his exoticism and virility, these elements also accentuate the cultural and ethnic differences that separate him from the heroine, whose English rose complexion and clear eyes are a national marker or metonymy of her Englishness. Her whiteness and the darkness of southern Europeans metaphorize the differences between the white north and the dark south, with all their accompanying cultural, gender, and ethnic imaginaries. 
For Homi K. Bhabha, colonial discourse is built on tropes and the "aggressive" need (2004, p. 110) to identify the Other with them, which demands that these stereotypes be constantly repeated. As Bhabha argues, “the same old stories of the Negro's animality, the Coolie's inscrutability or the stupidity of the Irish must be told (compulsively) again and afresh, and are differently gratifying and terrifying each time" (2004, p. 111). In romance fiction, the darkness of southern European men is something erotically gratifying and culturally terrifying. This rhetoric reproduces the cultural and colonial geography that splits northern and southern Europe. Because of the south's alleged primitiveness, the masculinity of its men is prefigured as naturally instinctive and virile.

For the fantasy to be complete, the exotic hero must evolve into a cultural hybrid. His half-acculturation is already a fact before he meets the heroine: he speaks perfect English, has studied in Britain, or travels often to it on business (cf. Teo, 2012, p. 235). Nevertheless, like the modern sheik heroes who have to "de-Orientalize" themselves (Teo, 2012, p. 232), the Latin hero must "learn to respect women's independence and treat them as equals" before he is deemed a "suitable partner" for the heroine (Teo, 2012, p. 233). Unlike the evolutionary pattern of the white Anglo-Saxon Protestant hero, that of the exotic alpha male evinces some degree of ethnic and gender essentialism associated with his country. His masculinity, as I will see in the next section, is shaped by cultural projections.

\section{The construction of Spanish masculinity}

In the 1970s, Spain was a preferred setting for many romance novels and a favorite destination for millions of British tourists. Although mass tourism contributed to the modernization of the country, Spain still retained about it an air of exoticism and difference. In British romance novels, Spain is often the land of the flamenco, the castanets, bullfighting, the fiesta, the siesta, and a blazing sun. References to the political situation-Spain was a 
dictatorship until Franco's death in 1975-are generally absent from the novels, except if we read them in between the lines. For, unlike Britain, Spain is depicted as a "still" country that remains stuck in traditions and lethargic motionlessness, something that continues to be so in the novels published in the early 1980s, even though Spain was already a democracy.

Spanish men are true masculine men who keep to the old gender codes. In Mills \& Boon romances from the sixties and seventies, words like courtesy, honor, passion, fury, and chauvinism qualify the Spaniards. Spain is “a man's country” (p. 27), writes Eleanor Farnes in A Castle in Spain (1971). Honor and cruelty are ingrained in the men. The "typical Spaniard," Winspear tells us in Dearest Demon (1975), is a man "in the mould of Don Quixote. His respect for honour is almost religious in its intensity and he wouldn't think twice about defending his honour by cutting to the bone the throat of his detractor" (pp. 164-165). Many of the novels lay emphasis on the Spaniards' manhood. The hero of Winspear's The Tower of the Captive is said to be "muy macho" (p. 93) and that of Dearest Demon is described as "very much a man, with that hard, definite virility that made Spaniards seem more masculine than other men" (pp. 52-53), something that Winspear curiously attributes to the fact that Spaniards "had none of that thickening of face and body of European men in their thirties; their bodies remained sleek and lithe, and their features had an El Greco distinctness" (p. 53). In Katrina Britt's The Guarded Gates (1973), Spaniards are said to be temperamental, "fervently masculine and courteous" (p. 12). They are of a different race to the English, whose "cool Saxon strain" contrasts with the "furia española or Spanish fury" (p. 68). The Moorish ancestry of Spaniards serves to further enhance their regressive masculinity.

In several of the novels, Spain and bullfighting are one and the same thing. In the most stereotypical manner, the heroine of Maura McGiveny's Duquesa by Default (1982) explains that she does not mind that the hero has been a matador because she "used to think all Spanish men fought bulls at one time or another and played the guitar and danced flamenco" (p. 126). 
Several scholars have referred to the bullfighter as an epitome of manhood. This image has featured prominently in literature and cinema (Schwenger, 1984; Marvin, 1988; FouzHernández, 2004). Bullfight is used by Winspear in two of her novels-The Kisses and the Wine (1973) and The Valdez Marriage (1978) — as a sexual metaphor for love and conquest: the "bull is the equivalent of male strength and virility. The cape is the grace and enticement of a woman. The sword . . is the thrust of sex" (p. 47), we read in the first of these novels. In The Valdez Marriage, the Spanish hero is even compared to a bull that, when provoked, will "breathe fire and attack" (p. 37). These tauromachian similes essentialize Spaniards as primitive, ungovernable, passionate, and fiery.

The fantasy of sexual fulfilment with these men was in the mind of British women seeking sexual tourism in Spain. Usually, these women were young and economically independent. Their liberal views about sex contributed to slowly change the "rigid sexual norms" existing under Franco (Godsland, 2006, pp. 229, 230). However, as Winspear says in Dearest Demon, the true Spaniard is not a "Don Juan" or a "Rudolph Valentino" (p. 164), as he is in the fantasies of northern European women who, hungry for romance (p. 53), come on holiday to Spain and "cheapen" themselves with Spaniards (p. 44). In tune with the gender conservatism of the novels, sexual tourism is invariably condemned, and so are the sexually liberated women and the Spanish Don Juans who will pursue them "volubly and passionately" and seduce them with their "almost hypnotic" words (Lane, 1978, p. 30). In Nurse in Tenerife, the heroine's nurse friend associates Spain with "sunshine and dolce vita" (p. 145) and “devastatingly dishy" men (p. 48). Carlos, the hero's chauffeur, is one of them: a handsome, self-conceited, sex-obsessed Casanova described as "Tenerife's gift to the tourist trade" ( $p$. 26). In Dearest Demon, we read that "liberated females" from northern Europe "flock to Spanish beaches" attracted by "Latin courtesy" and Spanish gentlemanliness. According to the heroine, "too much liberation does make women seem graceless, and it makes the men 
bad-mannered" (p. 54). In these novels, the true Spaniard is to be found inland, far from the tourist resorts. He is a virile male tied to the old codes of courtesy, the type of man that authors feel is rapidly disappearing from Britain.

\section{The literary rhetoric of Spanish masculinity}

In the following pages, I will analyze how Spanish masculinity is constructed in two representative novels: Pippa Lane's Nurse in Tenerife and Violet Winspear's The Valdez Marriage, both published in 1978 . The conflation of nation and masculinity becomes a determinant factor in the characterological construction of the novels' hero, particularly because the concept of Spanish masculinity is elaborated through discursive projections. Nurse in Tenerife is the only known novel by Lane; Winspear (1928-1989), instead, was one of Mills \& Boon's most prolific and "top-selling authors" (McAleer, 1999, p. 124) who set many of her novels in southern Europe.

Nurse in Tenerife features a hyper-heterosexualized alpha male of "splendid physique" and "aggressive strength" (p. 18). Miguel Martina, as he is called, is a famed neurosurgeon and the wealthiest man on the island. He feels immediately attracted to protagonist Trudy Forrest, who travels from England to the Canary Islands in Spain to nurse her stepmother. Miguel is a true Spaniard, a male chauvinist with an inflated ego, as Trudy sees him. She finds his masculinity insultingly overpowering and his body language aggressively masculine: his eyes have an "almost sensual glint of male triumph" (p. 29), his laughter is "almost contemptuous in its maleness" (p. 19), and his "muscular legs" are "set apart in an almost aggressively male stance" (p. 28). It is this "Iberian caveman" (p. 35) whom the highprincipled heroine will have to tame.

The trope of hunting conveys the rudimentary masculinity of Spaniards, which is on full display in the courtship game. Here, the man asserts his manhood by pursuing, capturing, and 
subduing his prey. For Miguel, the game is more challenging when the woman has "a touch of the English prude" (p. 29). He tries to win her surrender with ferocious kisses and wanton approaches. The narrative shows the rift between the Nordic and Latin character, and the superiority and more civilized nature of the former. While the English treat their women as equals and show them respect, Latins try to "dominate right from the start." They "have no finesse to play it cool and slow, as an Englishman would" (p. 44). The hero wants to possess Trudy, to make her yield to him, and be master over her. No Englishman — she observeswould address a woman in such a possessive manner, without respecting her liberty; "only a man with a Latin temperament" (p. 63). Miguel must learn to woo a woman "as tenderly, and as slowly, as any colder-blooded English might" (p. 55). He must restrain his "hot-blooded," impulsive masculinity (p. 97) before he can win the English heroine.

Despite its feminist claims, Nurse in Tenerife reaffirms a gender order that perpetuates hegemonic alpha masculinity. Although much critical emphasis has been placed on the taming of the hero (Radway, 1991; Krentz, 1992; Cohn, 1988; Regis, 2007; Taylor, 2007), Lane's novel puts it on a par with the taming of the independent, liberated heroine (cf. Bach, 1997) who, unable to resist the hero's charm and imperious masculinity, eventually surrenders to him. Connell's notion of "emphasized femininity" (1987, p. 183) is useful here to explain the 'alpha turn', as I will call it, underlying some romance novels. According to Connell, for the hero's hegemonic masculinity to exist, the woman must subordinate herself to his desires. At the novel's end, Miguel's Latin, domineering manhood appears in a positive light to Trudy, who wants to "surrender" to him and the "fire of desire" in his "Spanish eyes" (p. 183): "She knew that the glittering depths of his eyes held a wish to dominate, but in a way that would be such acceptable sweet surrender to her" (p. 183). The commanding tone of his voice, which was formerly regarded as a sign of his patriarchal power, is now seen as a symbol of his overwhelming masculinity: 
Now his tone was commandingly male, almost stern. 'Don't try to run away.'

She was awed by the sheer brute strength of him. 'I don't think I want to.'

She thrilled at the challenge in his tone. 'You wouldn't get two yards, cara, before I dragged you back.'

There was triumph in his domineering manner, a virile male reaction to the woman who was helpless in his charge, and happy to be so. Willingly, at this moment, she was ready to be his slave, do his every bidding in the game of love. (p. 184)

Although by the novel's end Miguel is tamed into a man of "infinite tenderness and understanding," he is, more than anything else, a "man of full sexual desires" (p. 182). Many authors of romance novels in the 1970s show their preference for a hybrid masculinity that combines "toughness" (Messner, 2007, p. 466) with "tenderness and understanding." This is likewise true of Lane's novel. Nevertheless, the narrative also essentializes fieriness and an unbridled sexual desire as instinctual drives that cannot be tamed in Latin men. It is this side of Miguel that makes him a true masculine man, "stronger and even more virile" than what the heroine "had imagined to be possible" (p. 186). His overbearing masculinity positions him as "the complete male" (p. 184). Despite being a liberated woman, Trudy acknowledges her need for a man that dominates her: "Liberated woman though she was, she still needed a man who had the power to dominate her, to insist on her surrender by the sheer force of the masculinity that he was now demonstrating so compellingly" (p. 185). Lane's novel moves from an initial feminist rhetoric to a reactionary, patriarchal discourse of love and feminist/feminine surrender. Like other romance heroines, Trudy is a modern version of Samuel Richardson's Pamela, who goes from initial rebellion to final submission. However independent and self-assertive the heroines may be or may have been, they need a man who "prove[s] himself the master always" (p. 115). The taming of the heroine ultimately confirms the traditional pattern of male superiority and female dependence. 
In the gender imaginary, Latin men have been "essentialized" as "vigorous and often violent," "romantic and emotional" (Cornwall \& Lindisfarne, 2017, pp. 12, 13). Winspear's novel The Valdez Marriage reproduces these stereotypes of the Latin man, who is portrayed as tempestuous, intensely passionate, cruel, and vengeful. Julio Valdez, the hero, fits into this type. He mercilessly obliges the heroine, Darcy Beaudine, to marry his crippled brother, who blames her for the accident that left him in a wheelchair.

As in other romance novels, in The Valdez Marriage Spain is depicted as "a land of passion, exotic travel, and erotic pleasure, but also essentially different, eccentric, primitive, and inferior" (Colmeiro, 2002, p. 143). Julio symbolizes all this. His mixed race adds to his hyper-heterosexualization: in Julio are combined the Moor, the Latin, and the Spaniard to produce a "sensually attractive" (p, 10), fascinatingly dark, and wildly virile man, the fantasy figure of "the macho Spaniard" (p. 112). The novel blends masculinity and ethnic evolution through a hierarchy that goes from the Moors to the Spaniards, whose gallantry makes them more civilized. Julio has the ruthless, "inflexible nature of an autocratic Moor" (p.10). His Moorish blood inherited from the "savage horsemen who had come riding into Spain" from the desert is still "running warm and strong" in his veins (p. 143). As a Latin man, his emotions are "fierce" and "almost primitive" (p. 109). As a Spaniard, he possesses the "unyielding sense of honour" (p. 153), the "Iberian gallantry" (p. 161), and the "pride and passion" (p. 123) of his fellowmen. Julio's "warm Spanish blood" (p. 44) and the "hot sun" of Andalusia in southern Spain run "tempestuously in [his] veins" (p. 35). He is "every inch a man” (p. 41). While his mixed-race hybridity increases his sexual attractiveness, it also categorizes him as a "throwback" (p. 27) and is the reason behind his rampant chauvinism. Julio represents a patriarchal culture that, in Darcy's eyes, ignores and seeks to crush her advanced views on gender. Darcy must learn to accept that "in Spain the man is the master" (p. 64) and women are "mere ornaments and chattels" (p. 18) that have to do as men order. 
At a symbolic level, Darcy's journey to Spain is a descent into an atavistic underworld. Winspear re-creates Andalusia as a land where time has stood still, anachronistically locked in medieval traditions. There are sprinkled references to the Moors, the conquistadors, and the Inquisition. Spain is eroticized as a land where the "sun touches everything with its savage lust," as opposed to the "cooler" sun of England (p. 118). It is into this world of savage passions, lust, and instincts represented by Spain that Darcy will descend.

Julio's darkness plays a central role in the heroine's katabatic journey. His powerful eroticism is constructed through frequent allusions to the virile sensuality of his darkness. $\mathrm{He}$ is "big and sensuously dark" (p. 135), is possessed of "vigorous dark" looks (p. 33), has a “dark sensual power" about him (p. 52), and is endowed with "dark supple strength" (p. 142) and “dark vitality" (p. 117). Winspear's novel constitutes a white woman's journey into dark Spain and the darkly virile masculinity—both "gratifying and terrifying" (Bhabha, 2004, p. 111) — of the Spanish hero. His real and symbolic darkness acts as the main catalyst of change. Julio awakens the heroine to her "animal sensuality" (p. 93), "primitive feelings" (p. 117) and untamed passions, which exist unbeknown to her and which would have never been released had she stayed in "cooler" England.

Many romance novels identify the exotic hero with "animality," in contrast to the "kinder, less exciting masculinity" (Kamblé, 2014, pp. 96, 97) of Englishmen. What is interesting in Winspear's novel is that the heroine experiences a gradual process of animalization as her unbound desire for the Spanish hero increases. His animal sexuality is insistently addressed in the text. He is compared to a bull, a "cougar with savage intentions" (p. 9), a "dark eagle" (p. 11), and an "Arab stallion" (p. 165). Initially referred to as his "prey" (p. 28), the heroine is gradually animalized as the story progresses and is eventually compared to the same animals - the cougar and the tiger - that describe Julio's ungovernable desire. On the novel's 
last page, reference is made to the "tigress" in Darcy (p. 189) that the Latin hero has been able to arouse.

\section{Conclusion}

In "The Construction of the Construction of Masculinities," Harry Brod claims that, when studying masculinity, it is vital not to "write women out of the picture," since masculinity is constructed in a continual negotiation with other men and with women (2011, p. 28). Romance novels not only write women in the picture; like all popular fiction, these texts are also a "barometer of the tastes [and] ideals" of their readers (McAleer, 1992, p. 10; cf. Kamblé, 2014, p. 21). Since the early novels published in 1908, imperialistic heroes, young boys, alpha heroes (Dixon, 1999, p. 63), beta males, single dads, and other male types have successively attracted the attention of women readers. In these narratives, the concept of masculinity is "multiple, contextual and historically shifting" (Messner, 2007, p. 462), which explains the genre's recent opening to other heretofore marginalized masculinities, such as those of homosexuals in male-male romance (Foster, 2015; Allan, 2016a), and disabled men (Baldys, 2012; Cheyne, 2013; Schalk, 2016). What a historical and situational approach to popular romance novels shows is the chameleonic nature of masculinity, which changes both through time and context.

Allan (2016b) argues that "the politics and representation of masculinity" in popular romance fiction has been a "largely unstudied area of inquiry in men's studies" (p. 27). In this article, I have focused on the intersection of nation and masculinity, with special reference to the Spanish alpha male and the conflict between his virile masculinity and the companionate, yet colorless, new masculinity of Englishmen. I have also tried to show the extent to which the rhetoric of colonialism underlies the representation of the exotic alpha hero. These novels, 
as I suggest, have been a vehicle through which ethnic ideologies have been buttressed by resorting to a rhetoric that contains the self and the Other within well-defined hierarchies.

Sociologist Gary D. Bouma contends that the "imagined other is more convenient than the awkward realities of a real other, that is, a real person or group" (2007, p. 194). While it is true that the publishers of romance fiction make their profit on stereotypical fantasy ideals of exotic masculinity, this should not make us forget that these imagined Others are inconvenient fantasies that draw on hierarchical ideologies.

\section{Notes}

${ }^{1}$ My use of the word 'exotic' is framed within cultural and touristic practices. As Hispanist Shelley Godsland (2006, p. 235) argues: “During the period of rapid development of Spain's tourist infrastructure, the Mediterranean was still sufficiently removed both geographically and culturally from Northern Europe for its inhabitants to be afforded . . . 'exotic,' and thus erotic, qualities, ... at least in popular tourist perceptions.”

${ }^{2}$ Research focused on Spanish masculinities has grown considerably since the 2000s, as has the number of masculinity scholars in Spain working in different areas. This interest has led to the establishment, in 2012, of the first Spanish journal entirely devoted to men's studies, Masculinities and Social Change.

${ }^{3}$ In the 1970s, the expression 'new man' applies only to the caring, nurturing man. In the 1980s, it also came to designate the narcissist man who follows the latest fashion trends and pays great attention to his personal appearance (Beynon, 2002, p. 164). 


\section{References}

Aliaga, J. V., \& Cortés, J. M. G. (2000). Identidad y diferencia: sobre la cultura gay en España [Identity and difference: Gay culture in Spain] (2nd ed.). Barcelona, Spain: Egales.

Allan, J. A. (2016a). Reading from behind: A cultural analysis of the anus. Regina, Canada: University of Regina Press.

Allan, J. A. (2016b). The purity of his maleness: Masculinity in popular romance novels. The Journal of Men's Studies, 24(1), 24-41.

Aresti, N. (2012). Masculinidad y nación en la España de los años 1920 y 1930 [Masculinity and nation in Spain in the 1920s and 1930s]. Mélanges de la Casa de Velázquez, 42(2), 5572.

Aresti, N., \& Martykánová, D. (2017). Masculinidades, nación y civilización en la España contemporánea: Introducción [Masculinities, nation and civilization in modern Spain: Introduction]. Cuadernos de Historia Contemporánea 39, 11-17.

Armengol-Carrera, J. M. (Ed.). (2012). Queering Iberia: Iberian masculinities at the margins. New York, NY: Peter Lang.

Bach, E. (1997). Sheik fantasies: Orientalism and feminine desire in the desert romance. Hecate, 23(1), 9-40.

Baldys, E. M. (2012). Disabled sexuality, incorporated. The compulsions of popular romance. Journal of Literary \& Cultural Disability Studies, 6(2), 125-141.

Beynon, J. (2002). Masculinities and culture. Buckingham, England: Open University Press.

Bhabha, H. K. (2004). The location of culture. New York, NY: Routledge. (Original work published 1994)

Blair, K. (1980). A nurse at Barbazon. London, England: Mills \& Boon (Original work published 1964) 
Borràs Català, V., Moreno Colom, S., Castelló Santamaría, L., \& Grau Casajust, A. (2012).

Male hegemony in decline? Reflections on the Spanish Case. Men and Masculinities 15(4), 406-423.

Bouma, G. D. (2007). Religious resurgence, conflict and the transformation of boundaries. In P. Beyer \& L. Beaman (Eds.), Religion, globalization and culture (pp. 187-202). Leiden, The Netherlands: Brill.

Britt, Katrina. (1973). The guarded gates. London, England: Mills \& Boon.

Britt, Katrina. (1977). The villa Faustino. New York, NY: Harlequin.

Brod, H. (2011). The construction of the construction of masculinities. In S. Horlacher (Ed.), Constructions of masculinity in British literature from the Middle Ages to the present (pp. 19-32). New York, NY: Palgrave Macmillan.

Burge, A. (2016). Representing difference in the medieval and modern Orientalist romance. New York, NY: Palgrave Macmillan.

Cartagena Calderón, J. R. (2008). Masculinidades en obras: El drama de la hombría en la España imperial [Masculinities in plays: The drama of manhood in imperial Spain]. Newark, DE: Juan de la Cuesta.

Cheyne, R. (2013). Disability studies reads the romance. Journal of Literary \& Cultural Disability Studies, 7(1), 37-52.

Cohn, J. (1988). Romance and the erotics of property: Mass-market fiction for women. Durham, NC: Duke University Press.

Colmeiro, J. F. (2002). Exorcising exoticism: 'Carmen' and the construction of Oriental Spain. Comparative Literature, 54(2), 127-144.

Connell, R. W. (1987). Gender \& power: Society, the person and sexual politics. Cambridge, England: Polity Press. 
Cornwall, A., \& Lindisfarne, A. (2017). Dislocating masculinity: Gender, power and anthropology. In A. Cornwall \& N. Lindisfarne (Eds.), Dislocating masculinity: Comparative ethnographies (pp. 11-45) (2nd ed). New York, NY: Routledge.

Dixon, J. (1999). The romance fiction of Mills \& Boon, 1909-1990. London, England: UCL Press.

Farnes, E. (1971). A castle in Spain. London, England: Mills \& Boon.

Foster, G. M. (2015). What to do if your inner tomboy is a homo: Straight women, bisexuality, and pleasure in $\mathrm{m} / \mathrm{m}$ gay romance fictions. Journal of Bisexuality, 15(4), 509531.

Fouz-Hernández, S. (2004). Crossing the border(line): Madonna's encounter with the Hispanic. In S. Fouz-Hernández \& F. Jarman-Ivens (Eds.), Madonna's drowned worlds: New approaches to her cultural transformations, 1983-2003 (pp. 138-157). Aldershot, England: Ashgate.

Fouz-Hernández, S., \& Martínez-Expósito, A. (2007). Live flesh: The male body in contemporary Spanish cinema. London, England: I.B. Tauris.

Frantz, S. S. G. (2009). Darcy's vampiric descendants: Austen's perfect romance hero and J. R. Ward's black dagger brotherhood. Persuasions On-Line, 30(1). Retrieved from http://www.jasna.org/persuasions/on-line/vol30nol/frantz.html

Gill, R. (2003). Power and the production of subjects: A genealogy of the new man and the new lad. The Sociological Review, 51(S1), 34-56.

Godsland, S. (2006). Francisco Umbral's "lady" tourists: A fictional view of early female visitors to Spain. Revista Canadiense de Estudios Hispánicos, 30(2), 225-248.

Guasch, O. (1995). La sociedad rosa [The pink society] (2nd ed.). Barcelona, Spain: Anagrama. 
Guasch, O. (2011). Social stereotypes and masculine homosexualities: The Spanish case. Sexualities, 14(5), 526-543.

Hartson, M. T. (2017). Casting masculinity in Spanish film: Negotiating identity in a consumer age. Lanham, MD: Lexington Books.

Jarmakani, A. (2015). An imperialist love story: Desert romances and the war on terror. New York, NY: New York University Press.

Kamblé, J. (2014). Making meaning in popular romance fiction: An epistemology. New York, NY: Palgrave Macmillan.

Krentz, J. A. (1992). Trying to tame the romance: Critics and correctness. In J. A. Krentz (Ed.), Dangerous men and adventurous women: Romance writers on the appeal of the romance (pp. 107-114). Philadelphia, PA: University of Pennsylvania Press.

Lane, P. (1978). Nurse in Tenerife. London, England: Mills \& Boon.

Marvin, G. (1994). Bullfight. Urbana, IL: University of Illinois Press. (Original work published 1988)

McAleer, J. (1992). Popular reading and publishing in Britain 1914-1950. Oxford, England: Clarendon.

McAleer, J. (1999). Passion's fortune: The story of Mills \& Boon. Oxford, England: Oxford University Press.

Messner, M. A. (2007). The masculinity of the Governator: Muscle and compassion in American politics. Gender \& Society, 21(4), 461-480.

McGiveny, M. (1982). Duquesa by default. Toronto, Canada: Harlequin.

Nash, M. (Ed.). (2014). Feminidades y masculinidades. Arquetipos y prácticas de género [Femininities and masculinities: Archetypes and gender practices]. Madrid, Spain: Alianza. Radway, J. A. (1991). Reading the romance: Women, patriarchy, and popular literature. Chapel Hill, NC: The University of North Carolina Press. (Original work published 1984) 
Regis, P. (2007). A natural history of the romance novel. Philadelphia, PA: University of Pennsylvania Press. (Original work published 2003)

Ryan, L., \& Corbalán, A. (Eds.). (2017). The dynamics of masculinity in contemporary Spanish culture. New York, NY: Routledge.

Schalk, S. (2016). Happily ever after for whom? Blackness and disability in romance narratives. The Journal of Popular Culture, 49(6), 1241-1260.

Schwenger, P. (2015). Phallic critiques: Masculinity and twentieth-century literature. New York, NY: Routledge. (Original work published 1984)

Taylor, J. (2007). And you can be my sheikh: Gender, race, and Orientalism in contemporary romance novels. The Journal of Popular Culture, 40(6), 1032-1051.

Teo, H. (2012). Desert passions: Orientalism and romance novels. Austin, TX: University of Texas Press.

Thorpe, K. (1973). Olive island. Toronto, Canada: Harlequin. (Original work published 1972)

Thorpe, K. (1974). An apple in Eden. London, England: Mills \& Boon. (Original work published 1973)

Winspear, V. (1974). The tower of the captive. London, England: Mills \& Boon. (Original work published 1966)

Winspear, V. (1975). Dearest demon. London, England: Mills \& Boon.

Winspear, V. (1979). The Valdez marriage. London, England: Mills \& Boon. (Original work published 1978)

Winspear, V. (1980). The kisses and the wine. London, England: Mills \& Boon. (Original work published 1973)

Winspear, V. (1981). The child of Judas. London, England: Mills \& Boon. (Original work published 1976) 